in the educational process of the institution of preschool education are characterized. It is emphasized that colored baths for feet can be used in the conditions of the PEl. The description of the methods of obtaining colored water in the PEl is given. The ways of using colored filters or light bulbs of different colors when working with children are described. The features of color puncture with preschool children and its impact on the human body are highlighted. Examples of diagnostic, graphic and rehabilitation exercises are given to diagnose emotional and mental state of children, improve mood and well-being, remove anxiety and stress. It is stated that color through the environment has a psychophysiological influence on the organism of children and the prospects for further studies of the features of the use of color therapy in didactic games and art therapy are determined.

Key words color, color therapy, wellness technologies, non-traditional means of healing, colored water, colored baths, diagnostic exercise, rehabilitation exercise.

удк 37.013.42:077.5-042.72]-053.67:791](045)

Нанулі Потьомкіна

Харківська державна академія культури

ORCID ID0000-0002-4269-3824

DOI 10.24139/2312-5993/2020.01/082-094

\title{
СОЦІАЛЬНО-ПЕДАГОГІЧНА ПРОФІЛАКТИКА ЗАЛЕЖНОСТІ СТАРШОКЛАСНИКІВ ВІД СОЦІАЛЬНИХ МЕРЕЖ ЗАСОБАМИ КІнОПРОДУКції
}

У статті проаналізовано й узагальнено особливості соціального розвитку старшокласників в умовах інформачійного суспільства. Відзначено, що актуальні сочіальні потреби старшокласників (спілкування, самопрезентація, кохання, дружба, визнання, популярність та ін.) знаходять свою реалізацію саме в кіберстосунках у сочіальних мережах, які, на додачу, технологічно побудовані таким чином, аби максимально заволодіти увагою й часом молоді, що, зрештою, призводить до нав'язливого потягу й залежності. Виходячи з основ сочіальновиховної парадигми пропонується розробка технологій сочіально-педагогічної профрілактики залежності старшокласників від сочіальних мереж, використовуючи обговорення й аналіз кінопродукції ігрового кіно.

Ключові слова: старшокласники; кіберпростір; кібер-залежність; залежність старшокласників від соціальних мереж; сочіально-педагогічна профрілактика; кінопродукція як засіб соціально-педагогічної профрілактики.

Постановка проблеми. В епоху інформатизації, у XXI столітті, інформація стала головною цінністю; відбувається формування й затвердження «інформаційної свідомості»; традиційні соціальні конфлікти перемістилися з реального матеріального простору в принципово новий кіберпростір або віртуальний простір, у якому шахрайсько-маніпулятивні технології набувають більш широкого застосування; розвиваються нові інформаційно-комунікаційні технології (IKT) та засоби масової комунікації (ЗМК). Завдяки останнім здійснюється вплив на масову свідомість, ведуться інформаційні мережеві протистояння й кібервійни, знищуються окремі 
суб'єкти й цілі країни. Проте, саме ЗМК (кіно, телебачення, Інтернет) займають найбільшу кількість життєвого простору молодої генерації. Кожна людина, зокрема юнаки та дівчата старшого шкільного віку, зважаючи на притаманні їм особливості соціального розвитку (підвищена потреба в комунікації, інтерес до створення романтичних стосунків, самопрезентація, самоактуалізація та ін.), мають потребу в щоденному спілкуванні й обміні інформацією. Сучасні віртуальні соціальні мережі дають небачені для цього можливості: спілкування з людьми різного віку, статі, етносу, релігії тощо; участь у масових обговореннях актуальних проблем на форумах і в чатах; можливість швидкого доступу до новин всесвітнього масштабу; самопрезентація відповідно до уявлень юні про своє «внутрішнє Я»; самореалізація творчих ідей тощо. Проте, як і в кожному явищі соціальної дійсності, у віртуальних соціальних мереж є і свої недоліки, зокрема - зміни в соціальному розвитку молодого покоління через трансформацію (обумовлену появою та розвитком кібер-соціальності) реальної соціальності, що мають прояв не лише традиційних деформацій (наркоманія, алкоголізм, протиправна поведінка тощо), але й нових видів залежностей. Зауважимо, що кіберпростір є важливим фактором формування особистості в сучасній культурі, оскільки багато аспектів культури нині набувають форми віртуальності, однак надмірне захоплення ним призводить до кіберзалежності (у даному випадку - залежність від соціальних мереж). Базуючись на засадах соціально-виховної парадигми соціальної педагогіки, прагнемо підвищити ефективність соціально-педагогічної профілактики залежності старшокласників від соціальних мереж шляхом використання засобів кінопродукції ігрового кіно, з метою зменшення, чи навіть подолання, негативного стихійного впливу соціальних мереж (поширення деструктивних угрупувань у соціальних мережах; екстремальні селфі, що призводять до нещасних випадків; кібербулінг; секстінг; кібер-домагання тощо) і збільшення частки позитивного прояву їх використання (оперативність комунікації; розширення кола знайомих; створення активних просоціальних груп за інтересами; долучення до соціальних проєктів у спільнотах та ін.), з метою взаємообумовленого розвитку кібер- та реальної соціальностей старшокласників і гармонізації соціального розвитку молодої генерації в цілому.

Аналіз актуальних досліджень. Психологічні особливості соціального розвитку старшокласників представлені в працях І. Беха, Е.Гуцало, О. Запорожця, І. Кона, О. Леонтьєва, О. Меньших, Ю. Петренка та ін. Питання кібер-залежності досліджується зарубіжними (К. Аймедов, Т.Больбот, Є. Войскунський, О. Катков, Л. Юр'єва, Р. Арджан (R. Arjan), М. Гріффітс (M. Griffits), М. Орзак (M.Orzack), К. Янг (K. Young) та ін.), а також вітчизняними (О.Бартків, Т. Веретенко, О. Камінська, Т. Мартинюк, Н. Сергєєва, К. Ярмоленко та ін.) авторами. Місце та вплив соціальних мереж 
у розвитку молодого покоління представлені в дослідженнях науковців різних галузей, а саме: філософський аспект (Ю. Данько, А. Назарчук, О. Шапіро та ін.); психологічний аспект (О. Бондарчук, Т. Галіч, О. Зінченко, Я. Чаплан, Г. Чуйко та ін.); соціокультурний аспект (К. Батаєва, О. Івушкіна, Н. Ізотова, П. Латі, І. Сілютіна, Г. Солдатова та ін.); комунікативний аспект (А. Берко, Л.Городенко, І. Кушнірецька, Н. Малєєва та ін.); соціальнопедагогічний аспект (І. Парфенюк, І Титаренко, Є. Шилова та ін.). Місце засобів масової комунікації в процесі соціального розвитку молодої генерації, зокрема вплив мультфільмів і кіно, висвітлено в наукових тезах Г. Акутіної та С. Акутіної, М. Вдовіної, Є. Вейцмана, Д. Георгієвської, Л. Казачкової та ін. Прихильниками соціально-виховної парадигми соціальної педагогіки виступають вітчизняні науковці О. Білик, Н. Заверико, Н. Максимовська, О. Рассказова, А. Рижанова, С. Харченко та ін. Соціальнопедагогічну профілактику кібер-залежності молодого покоління досліджують Т. Веретенко, С.Дембіцька, О. Лісова, В. Махновець та ін. Однак, слід зазначити, що соціально-педагогічні можливості комерційних фільмів ігрового кіномистецтва відповідного сюжету в контексті соціальнопедагогічної профілактики залежності старшокласників від соціальних мереж досі не були розглянуті.

Метою даної статті $€$ уточнення поняття кібер-залежність та їі різновидів, із метою визначення особливостей соціально-педагогічної профілактики залежності старшокласників від соціальних мереж засобами кінопродукції.

Методи дослідження. Аналіз наукової літератури з проблеми, систематизація й узагальнення досвіду науковців із питання кіберзалежності, диференціація та систематизація кінопродуктів відповідно до соціальних якостей особистості старшокласників.

Виклад основного матеріалу. Юність - це не просто етап дорослішання, це етап формування цілісного образу «я». Віковий період із 15 до 18 років є дуже важливим в онтогенезі людини: навчання в старшій школі й подальший професійний вибір; розширення діапазону соціальних ролей у суспільстві (отримання паспорту з 14 років (Закон України, 2016, № 1474-VIII); право на шлюб при досягненні шлюбного віку, який становить 17 років - для жінки та 18 років - для чоловіка, а також зниження шлюбного віку за заявою особи та за рішенням суду в окремих випадках навіть 3 14 років відповідно до Сімейного Кодексу України (Сімейний Кодекс України, ст.22-23) та ін.); формування здатності до інтимної юнацької дружби й романтичного кохання (Гуцало, н.д.); загострення потреби в приналежності та прийнятті, яка реалізується, передусім, у спілкуванні та ін. Як зазначає Е. Гуцало, «...спілкування в юнацькому віці будується на суперечливому переплетінні двох потреб: уособлення й потреби в приналежності, а також входженні до певної групи...» Ошибка! Источник ссылки не найден.(Гуцало, н.д.). Науковець вважає, що спілкуванню юні притаманні дві протилежні 
тенденції: поглиблення обсягу спілкування (зростання часу, який витрачають на нього, розширення його соціальної сфери, постійне прагнення до контактів) та індивідуалізація, яка проявляється у вимогливості та вибірковості до контактів спілкування (Гуцало, н.д.). Зважаючи на зазначені психовікові особливості юні та притаманні віртуальним соціальним мережам (Інстаграм («Instagram»), Лінкедін («Linkedln»), Майспейс («MySpace»), Твіттер («Twitter»), Фейсбук («Facebook») та ін.) технологічні властивості (зручний і компактний інтерфейс, швидкість доступу, оперативність зміни налаштувань, систематизація контенту тощо), не дивно, що спілкування у віртуальному просторі стало домінуючим засобом комунікації старшокласників інформаційної доби.

Кожна віртуальна соціальна мережа представляє собою певну інноваційну кіберкультуру, тому погоджуємося з Т. Галіч, яка стверджує, що «наповнення соціальної мережі - це індикатор розвитку суспільства» (Галіч, 2014). Віртуальні соціальні мережі переповнені інформацією, що представляє інтерес для юнацтва: новини про міста/країни/світ; знаменитостей (їх творчі чи спортивні успіхи, сімейні стосунки, події 3 життя та ін.); актуальні кінопрем'єри; випуски нових музичних альбомів; фотогалереї різної тематики та багато іншого. Акаунт користувача (обліковий запис) є своєрідним деталізованим соціально-психологічним досьє на людину - він має певний структурований контент (наповнення) 3 інформацією про власника (нік у вигляді реального ім'я чи псевдоніму; фото; стать; дата народження й подібне, що складають картину самопрезентації суб'єкта); факти про улюблені місця для відпочинку й хобі (прояв соціальної активності); приналежність до соціальних угрупувань і спільнот (ідентифікація себе з тою чи іншою групою); цікаві світлини, кіно, музичні смаки, літературні вподобання (коло інтересів, яке складає картину цінностей суб'єкта) та ін. Проте, не слід забувати, що спілкування в Мережі відбувається опосередковано через комп'ютер/смартфон/планшет із доступом до Інтернету та воно не може передати всю «палітру відчуттів», які $\epsilon$ в реальному спілкуванні. Співрозмовники не можуть відчути миттєві емоції під час розмови, розпізнати жести й пози опонента, побачити міміку один одного, а, як відомо, основну частину інформації людина отримує через зір, однак за відсутності цього каналу вона може хибно інтерпретувати отримане повідомлення. Зауважимо, що навіть під час відео-чату за допомогою відео-камери в режимі онлайн трансляції користувач позбавлений можливості відчувати запахи, температуру навколишнього середовища свого співрозмовника та ін. Н. Малєєва робить акцент на такому негативному прояві використання соціальних мереж, як спрощення комунікативної культури (Малєєва, 2016). Автор вважає, що під час листування зазвичай скорочуються речення, щоб максимально стисло 
передати інформацію; допускаються орфографічні та пунктуаційні помилки аби швидше набрати й надіслати повідомлення (Малєєва, 2016); деякі слова заміняються спеціальними символами чи специфічним сленгом/абревіатурою (наприклад, «сміюся дуже голосно» «LOL»/laughing out loud) та ін. Таким чином спрощуючи комунікативний акт, юнаки та дівчата, які не мають альтернативи реального спілкування, втрачають не тільки комунікативні навички, а й навички реальної безпосередньої соціальної взаємодії. Тривале перебування старшокласників у віртуальних соціальних мережах має й інші негативні соціальні наслідки: безцільний серфінг акаунтами друзів/знайомих/знаменитостей (перегляд подій із життя, історій, коментарів, фотоальбомів та ін.); зменшення різногалузевих потоків інформації як наслідок утворення «інформаційного пузиря»; занурення в кіберпростір із відходом від реального соціального життя (старшокласник намагається кожну вільну хвилину перебувати в соціальних мережах: під час поїздки в громадському транспорті й очікуючи в черзі; замовляючи страви в кафе; відпочиваючи з друзями; під час перегляду телевізору в сімейному колі; під час уроків у школі та ін.); розвиток кібер-залежності.

Серед зростаючого обсягу зарубіжних досліджень (Катков, 2012; Young, 2000; Arjan, 2008), поняття кібер-залежність поширилося здебільшого в психіатричній лексиці, однак вважаємо доцільним відзначити трактування психолога К. Янг (K. Young), оскільки саме їі наукові положення дали основу для подальших зарубіжних і вітчизняних науковців різних галузей. Автор оцінює кібер-залежність як стан проблемного використання Інтернету, пов'язаного зі значними соціальними, психологічними та професійними порушеннями. Основними симптомами, які характеризують цей стан, виступають: безцільна зайнятість Інтернетом протягом тривалого часу; посилення тривоги в періоди, коли немає доступу до Мережі; уникнення розмов про реальний час проведення в кіберпросторі; розлади в реальному соціальному житті (соціальна ізоляція, посилення депресії, сімейні чвари, академічні невдачі, фінансові заборгованості тощо) (Young, 2000; Arjan, 2008). Також науковець вважає, що залежність від Інтернету може набувати вигляду: залежності від кібер-стосунків (надмірне захоплення Інтернетстосунками), нав'язливих станів в Інтернеті (шопінг, торгівля, азартні ігри), кіберсексуальна залежність (відвідування порно-сайтів, кіберсекс), інформаційного серфінгу (безцільне блукання інформаційними сайтами), ігрової залежності (нав'язливий потяг до комп'ютерних ігор) (Young, 2000). Так, Н. Сергєєва розглядає кібер-залежність з позиції саме ігрової залежності та визначає ії як «...різновид девіації особистості, якій характерна штучна зміна психологічного стану й ціннісних пріоритетів у результаті зосередження уваги на ігровій комп'ютерній діяльності, що заміщує реальне життя або сприяє уникненню відповідальності, складних проблем, пошуку шляхів їх 
розв'язання, задовольняє потребу щодо вияву емоцій у змодельованих ігрових ситуаціях і компенсує дефіцит соціальних контактів, соціальних домагань і безпосереднього спілкування з однолітками і в сімейному середовищі» (Сергєєва, 2010). Ураховуючи ці наукові тези додамо, що Т. Мартинюк вважає «одним із основних механізмів формування залежності- перенесення емоційного ставлення 3 живого об'єкта на неживий, або навпаки - ставлення до живого як до неживого» (Мартинюк, 2014). Ця думка підтверджує дослідження зарубіжних науковців стосовно того, що кібер-залежність виникає як наслідок проблем, які є в людини в реальному соціальному просторі (проблеми в навчанні, непорозуміння 3 батьками, суперечки з друзями, самотність, залежність від азартних ігор, сексуальні девіації та ін.), а віртуальна реальність у такому випадку виступає засобом для задоволення потреб, які людина не може реалізувати в реалі. Погоджуючись із дослідниками (Катков, 2012; Бондарчук, 2013; Young, 2000), вважаємо, що для формування в старшокласників залежного від кіберпростору стану слугують різні соціальні фактори й умови, в яких вони проживають. Так, наприклад, у старшокласників це, насамперед, невдоволення власним зовнішнім виглядом, дефіцит реального соціального спілкування, відсутність уваги з боку протилежної статі, замкнутість і соціальна пасивність можуть знайти відображення в надмірному захопленні сайтами знайомств (реалізовуючи таким чином потреби в спілкуванні та створенні романтичних стосунків) і активною діяльністю в соціальних мережах, шляхом публікації постів і фото аби звернути на себе увагу, а також велика кількість підписок і віртуальних друзів-підписників, аби компенсувати дефіцит у реальному соціумі та подібне.

Зважаючи на відсутність єдиної думки науковців різних галузей щодо причин, особливостей виникнення та проявів кібер-залежності, досі немає достатніх підстав для внесення її до Міжнародного класифікатора хвороб, як інші патологічні стани (алкогольна та наркотична залежності, сексуальні девіації, обсесивно-компульсивні розлади та ін.) і не існує й єдиного профілактичного комплексу для попередження її появи. Проте, враховуючи підвищений інтерес і занепокоєння щодо проблеми та зростаючої кількості залежного контингенту по всьому світу (Катков, 2012; Мартинюк, 2014; Young, 2000; Arjan, 2008), поширюється практика розробки й упровадження різноманітних стратегій профілактики кібер-залежності. Так, наприклад, у Китайській народній республіці та в Північній Кореї донедавна школярів із діагностованою кібер-залежністю направляли до спеціалізованих навчальновиправних таборів, а також застосовували електрошок для лікування (https:// vc.ru/offline/63797-ot-elektroshoka-do-lagerey-dlya-vzroslyh-kak-lechatinternet-zavisimost-vo-vsem-mire). У США основні стратегії лікування кіберзалежності включають когнітивно-поведінкові підходи, терапію сексуальних девіацій і злочинних дій сексуального характеру, сімейну терапію, навчання 
соціальних навичок і фармакологічні втручання (Young, 2000). Російський досвід, апробований у Казахстані, пропонує низку технологій профілактики серед дітей старшого шкільного віку: психофармакотерапевтичне лікування; індивідуальне й сімейне адиктологічне консультування; ескпреспсихотерапія початкових проявів Інтернет-залежності; програма «FAST» сім'я та школа разом (Катков, 2012). На наш погляд, саме остання може бути ефективною для реалізації в українському суспільстві, оскільки скоординована цілеспрямована взаємодія фахівців (шкільних психологів, соціальних педагогів та ін.) з батьками та дітьми, які навчаються в даному закладі освіти з метою підвищення їх рівнів адаптації, соціалізації та успішності в побуті, школі й товариствах - притаманна демократичному підходу усунення чи попередження залежності молодої генерації. Українські науковці Т. Веретенко й К. Ярмоленко (Веретенко \& Ярмоленко, 2018) 3 метою соціально-педагогічної профілактики кібер-залежності, пропонують підвищувати поінформованість стосовно безпечного використання Мережі, використовувати тренінги, створювати й підтримувати сприятливу атмосферу в сім'ї, задовольняючи основні потреби старшокласників у любові, довірі, увазі, прийнятті.

Відзначимо, що на сьогодні саме соціально-педагогічна профілактика, як комплекс різноманітних засобів (психологічні, педагогічні, медичні, соціальні, художні тощо) попередження виникнення негативних тенденцій у молодого покоління, вважається найбільш результативною, оскільки реалізується шляхом підвищення ефективності педагогічного процесу, зокрема зменшенням впливу негативних факторів об'єктивної дійсності й підсиленням позитивних. Зауважимо, що останнім часом актуалізувалося використання засобів мистецтва як профілактичного інструменту, а саме кінематографу, який зазнав значних трансформацій у зв'язку з розвитком технологічних інновацій. Так, наприклад, Л. Казачкова вважає, що використання кіно (як у відеоформаті, так і в ефірному часі телетрансляції) буде доцільним у сфері дозвілля сучасних школярів. Також науковець наголошує, що подібний засіб покращить виховний процес, за умови посилення педагогічного керування та його спрямування (Казачкова, 2014). Погоджуючись з автором. Відзначимо, що у вітчизняній соціальнопедагогічній практиці можливість впливу кіномистецтва на молоде покоління здебільшого розглядається з позиції соціального кіно й соціальної реклами, які створюють на некомерційній основі з метою: попередження негативних явищ у суспільстві; за мотиватора просоціальної поведінки; пропагування соціально-схвалюваних дій; як стимул до власного соціального розвитку й гармонізації суспільства в цілому. Так, наприклад, у межах реалізації конкурсу соціальної реклами, був представлений міні-проект «Профілактика Інтернет-залежності школярів» студента Східноєвропейського національного університету імені Лесі Українки В. Махновця (Махновець, 
н.д.). І, звичайно ж, не варто недооцінювати роль даного продукту, однак відзначимо, що подібних відеопроектів і реклами, а також плакатів/постів/брошур недостатньо як у телевізійному ефірі, так і в Інтернеті. В останньому, зокрема, перед користувачем стоїть завдання знайти саме цей актуальний контент і саме цього відповідного змісту й не потрапити в «смітник з інформаційним брудом». Однак, варто зазначити, що, зважаючи на соціокультурні перетворення інформаційної доби, інноваційну технологізацію створення кінопродукту, зміну соціальної ситуації розвитку та трансформацію потреб сучасного юнацтва, - можливе використання популярного комерційного кінопродукту, який буде не тільки актуальним і цікавим для юнаків та дівчат, але й відповідатиме соціально-виховній меті на шляху соціально-педагогічної профілактики залежності старшокласників від соціальних мереж. Так, наприклад, можна використовувати перегляд і обговорення кінофільмів:

1) для виховання соціальної суб'єктності: «Диво», «Стражі Галактики», «Люди Х», «Хроніки Ріддіка», «Люсі», «47 ронінів», «Месники» та ін.;

2) для розвитку гуманності й соціальної толерантності: «Хлопчик у смугастій піжамі», «Життя Пі», «Інопланетянин», «1+1», «Трансформери», «Черепашки ніндзя» та ін.;

3) з метою формування та збереження сімейних цінностей: «Сім'янин», «Капітан Фантастік», «Сімейка Адамс» та ін.;

4) турбота про природу й навколишній світ: «Чарівниця», «Маліфісента», «Фантастичні звірі і де їх шукати» та ін.;

5) відповідальність: «Брюс Всемогутній», «Еван Всемогутній», «Клік $з$ пультом по життю», «12», «Персі Джексон та викрадач блискавок» та ін.

Зауважимо, що саме соціально-педагогічна діяльність у закладах загальної середньої освіти (З3СО) сприяє взаємодії закладу, сім'ї та суспільства у вихованні покоління, що підростає. Зважаючи на актуальність поставленої проблеми кібер-залежності серед старшокласників вважаємо за необхідне підвищити ефективність цілеспрямованої соціальнопедагогічної діяльності, зокрема її превентивний напрям - соціальнопедагогічну профілактику, яка полягає в роботі на середовищному внутрішньо-шкільному рівні, де можуть бути організовані: круглі столи 3 батьками з приводу безпечної поведінки в Інтернеті та профілактики кібербулінгу; інформаційні вебінари для вчителів 3 основ медіаграмотності; кіноклуб для обговорення кінопродуктів, направлених на розвиток соціальної суб'єктності учнів старшої школи; створення груп у соціальних мережах для обміну інформацією (корисний контент), проведення акцій (просоціальні виклики), створення кінотеки та ін.; на середовищному зовнішньо-шкільному рівні соціальний педагог може: організувати похід до кінотеатру для перегляду фільму відповідного змісту 
з його подальшим обговоренням; залучити лідерів думок і популярних блогерів для спілкування зі старшокласниками; відвідати відділ кіберполіції з метою ознайомлення зі структурою даного підрозділу та просвіти щодо його основної діяльності та ін.; на особистісному внутрішньо-шкільному рівні - інформування й консультування старшокласників про кібер-злочинців і шахрайські технології маніпулювання, використання персональних даних через соціальні мережі зі злочинною метою; попередження про небезпеки екстремальних селфі та ін.; на особистісному зовнішньо-шкільному - залучення спеціалістів ITсфери й комп'ютерних технологій для інформування про шляхи захисту від кібер-злочинців і захисту персональних даних.

Висновки. Таким чином, узагальнюючи аналіз, поданий у статті, відзначимо, що:

1) старшокласники - особи юнацького віку (від 15 до 18 років), які прагнуть здобути повну загальну середню освіту в 33СО, яка в умовах інформаційного суспільства покликана забезпечити не лише всебічний інтелектуальний розвиток молодої генерації, але й сприяти вихованню й соціалізації особистості здобувача освіти шляхом удосконалення характерних особливостей соціального розвитку старшокласників: збільшення соціальних ролей у суспільстві; громадянська активність; потреба в приналежності; готовність до свідомого професійного самовизначення; прагнення до спілкування; індивідуалізація та ін.;

2) стихійне перебування в Мережі може призвести до виникнення в старшокласників нав'язливих станів і залежностей, які можуть мати прояв нереалізованих у реальному житті потреб: захоплення азартними іграми й шопінгом; безцільний серфінг в Інтернеті; ігрова залежність; тяжіння до кіберсексу; залежність від соціальних мереж;

3) залежність від соціальних мереж (Інстаграм («Instagram»), Фейсбук («Facebook»), Твіттер («Twitter») та ін.), як один із видів кіберзалежності, все більше набуває поширення серед старшокласників, як найбільш активної та прогресивної категорії населення, має прояв заміщення реального спілкування віртуальною комунікацією та стосунками, що в результаті призводить до деформації реальної соціальності молодої особистості;

4) «профілактика», як міжгалузевий науковий термін позначає комплекс запобіжних засобів (психологічні, педагогічні, медичні, соціальні, правові, художні тощо) з метою попередження й усунення негативних факторів, що зумовлюють виникнення й поширення відхилень і залежностей; специфікою соціально-педагогічної діяльності є: зміцнення позитивних об'єднаних зусиль із боку школи, батьків, закладів культури, самої людини й однолітків, а також нейтралізацію негативних факторів соціального середовища (у даному випадку неконтрольоване й 
незахищене перебування у віртуальних соціальних мережах) на особистість, з метою попередження кібер-залежності; у даному випадку їі ефективність обумовлена використанням різноманітних засобів мистецтва, зокрема кіномистецтва;

5) кінопродукція як засіб соціально-педагогічної профілактики активно використовується для: урізноманітнення сфери дозвілля, формування громадянської позиції, виховання моральних почуттів та ін. Однак, з метою виховання відповідальності слід використовувати перегляд і обговорення фільмів - «12», «Персі Джексон та викрадач блискавок»; виховання соціальної суб'єктності - «Стражі Галактики», «Люди Х»; збереження сімейних цінностей «Капітан Фантастік» та ін.;

6) соціально-педагогічну профілактику залежності старшокласників від соціальних мереж слід структурувати за такими рівнями: середовищний внутрішньо-шкільний (кіноклуби, круглі столи з батьками стосовно кібербуллінгу тощо) і зовнішньо-шкільний (похід до кінотеатру, екскурсія до відділу кіберполіції); особистісний внутрішньо-шкільний (бесіди та просвіта щодо небезпеки екстремальних селфі, захисту персональних даних у Мережі та ін.) і зовнішньо-шкільний (спеціалісти ITсфери для консультування щодо заходів захисту від кібер-злочинців). Подібні заходи на різних рівнях реалізації соціально-педагогічної діяльності уможливлять запобігання виникнення залежності старшокласників від соціальних мереж і сприятимуть недопущенню негативних проявів (залежність від віртуальних стосунків, відсутність соціальних і комунікативних навичок реального спілкування та ін.) соціального розвитку молодого покоління.

Перспективи подальших наукових розвідок. $у$ подальших дослідженнях означеної проблеми доцільною є систематизація зарубіжного досвіду профілактики залежності старшокласників від соціальних мереж.

\section{ЛІТЕРАТУРА}

Бондарчук, О. І. (2013). Психологічні особливості взаємодії у віртуальних соціальних мережах. Вісник Чернігівського начіонального педагогічного університету, Психологічні науки, 114, 7-11. (Bondarchuk, 0. I. (2013). Psychological features of interaction in virtual social networks. Bulletin of the T.H. Shevchenko National University, Psychological Sciences, 114, 7-11).

Веретенко, Т., Ярмоленко, К. (2018). Соціально-педагогічна профілактика інтернетзалежності. Актуальні питання гуманітарних наук: міжвузівський збірник наукових праць молодих вчених Дрогобицького державного педагогічного університету імені Івана Франка, 19, T. 1, 145-149. (Veretenko, T., Yarmolenko, K. (2018). Socio-pedagogical prevention of Internet addiction. Humanities science current issues: Interuniversity collection of young scientists' research papers of Drohobych Ivan Franko State Pedagogical University, 19, V. 1, 145-149).

Галіч, Т. О. (2014). Соціальні мережі Інтернет як агент соціалізації молоді. Сучасні суспільні проблеми у вимірі соціології управління: збірник наукових праць ДондуУ, Т. 15, 
281, 250-256. (Halich, T. 0. (2014). Social networking Internet as an agent of youth socialization. Contemporary social problems in measuring the sociology of management: a collection of DonSUU scientific works, V. 15, 281, 250-256).

Гуцало, Е. У. (н. д.). Соціальна ситуація розвитку старшокласника. Режим доступу: https://wiki.cuspu.edu.ua/index.php/Гуцало 8.2. Соціальна ситуація розвитку с таршокласника. Провідна_діяльність. (Hutsalo, E. U. The social situation of high school students' development. Retrieved from: https://wiki.cuspu.edu.ua/index.php/Гуцало_8.2._Соціальна_ситуація_розвитку с таршокласника. Провідна діяльність).

Закон України «Про внесення змін до деяких законодавчих актів України щодо документів, що підтверджують громадянство України, посвідчують особу чи їі спеціальний статус, спрямованих на лібералізацію Європейським Союзом візового режиму для України» (2016). (Law of Ukraine «Amendments' to certain legislative acts of Ukraine concerning documents certifying the citizenship of Ukraine certify a person or his special status aimed at liberalization by the European Union of the visa regime for Ukraine»). Retrieved from: https://zakon.rada.gov.ua/laws/show/1474-19.

Казачкова, Л. М. (2014). Кіномистецтво як ефективний засіб виховання учнів. Таврійський вісник освіти, 2(46), 228-236. (Kazachkova, L. M. (2014). Cinema as an effective way of students' educating. The Taurian Bulletin of Education, 2(46), 228-236).

Катков, А. Л. (2012). О психологических и медицинских аспектах негативного влияния компьютерной зависимости на несовершеннолетних: методические рекомендации. Павлодар. (Katkov, A. L. (2012). About psychological and medical aspects of the computer addiction negative impact on minors: guidelines. Pavlograd).

Малєєва, Н. С. (2016). Комунікативна поведінка залежних від соціальних мереж користувачів. Педагогічний процес: теорія і практика, 1(52), 74-78. (Malieieva, N. S. (2016). Communicative behavior of the users addicted to social networks. Pedagogical Process: Theory and Practice, 1(52), 74-78).

Мартинюк, Т. А. (2014). Теоретичні засади проблеми формування комп'ютерної залежності серед дітей та підлітків. Вісник Чернігівського національного педагогічного університету. Педагогічні науки, 122, 155-159. (Martyniuk, T. A. (2014). The theoretical basis of computer addiction formation problems' among children and adolescents. Cherkasy University Bulletin: Pedagogical Sciences, 122, 155-159).

Махновець, В. Профрілактика інтернет-залежності школярів. Режим доступу: http://eprints.zu.edu.ua/16603/1/Махновець.pdf. (Makhnovets, V. Schoolchildrens' Internet Addiction Prevention. Retrieved from: http://eprints.zu.edu.ua/16603/1/ Махновець.pdf.)

Om электрошока до лагерей для взрослых: как лечат интернет-зависимость во всём мире. Режим доступа: https://vc.ru/offline/63797-ot-elektroshoka-dolagerey-dlya-vzroslyh-kak-lechat-internet-zavisimost-vo-vsem-mire. $\quad$ (From electroshock to adult camps: how Internet addiction is treated around the world. Retrieved from: https://vc.ru/offline/63797-ot-elektroshoka-do-lagerey-dlyavzroslyh-kak-lechat-internet-zavisimost-vo-vsem-mire.)

Сергєєва, Н. В. (2010). Соціально-педагогічні умови профрілактики комп'ютерної адикції підлітків (автореф. дис. ... канд. пед. наук: 13.00.05). Київ. (Serhieieva, N. V. (2010). Socially-pedagogical conditions prevention of computer addiction of teenager (PhD thesis). Kyiv). 
Педагогічні науки: теорія, історія, інноваційні технології, 2020, № 1 (95)

Сімейний Кодекс України. стаття 22-23. Режим доступу: https://zakon.rada.gov.ua/laws/show/2947-14. The Family Code of Ukraine, Article 22-23. Retrieved from: https://zakon.rada.gov.ua/laws/show/2947-14.

Arjan, R., Pfeil, U., Zaphiri, P. (2008). Age Differencesin Online Social Networking. CHI Proceedings Works In Progress (Florence, Italy), April 5-10, 2739-2744.

Young, K. (2000). Cyber-Disorders: The Mental Health Concern for the New Millennium. Cyber Psychology \& Behavior, 3(5), 475-479.

\section{PEЗЮME}

Потёмкина Нанули. Социально-педагогическая профилактика зависимости старшеклассников от социальных сетей средствами кинопродукции.

В статье проанализированы и обобщены особенности социального развития старшеклассников в условиях информационного общества. Отмечено, что актуальные социальные потребности старшеклассников (общение, самопрезентация, любовь, дружба, признание, популярность и др.) находят свою реализацию в киберотношениях в социальных сетях, которые технологически построены таким образом, чтобы максимально овладевать вниманием и временем молодежи, что в конце концов приводит к навязчивому влечению и зависимости. Исходя из основ сочиальновоспитательной парадигмы предлагается разработка технологий социальнопедагогической профилактики зависимости старшеклассников от социальных сетей, используя обсуждение и анализ кинопродукции игрового кино.

Ключевые слова: старшеклассники; киберпространство; кибер-зависимость; зависимость старшеклассников от социальных сетей; социально-педагогчческая профрилактика; кинопродукция как средство сочиально-педагогической профилактики.

\section{SUM MARY}

Potomkina Nanuli. Social and pedagogical prevention of high school students' dependence on social networks by means of film production.

Transformation of socio-cultural space as a result of transition to the information society and change of basic communication technologies are manifestations of innovative information age that is carrying new challenges (mastering cyberspace, adapting to new channels communication, social features interaction development through innovative hardware, etc.) and threats (manipulation, cyberattacks, cyber fraud, cyberbullying, Internet addiction, etc.) especially for the young generation, cause that they unconsciously integrate the internet throughout their lives as active consumers. The Internet, as a relatively new form of media is different from other mass media because of its interactive ability, that is, the possibility of users interacting with a machine, virtual communities and individuals, globally. There are increasing numbers of papers on the topic of excessive Internet use which are so diverse and of such differing methodological quality. In this article it has been mentioned that in the studies of sociologists, psychologists, or psychiatrists from different countries around the globe the Internet addiction still has not been formally identified as a problematic behavior or illness. Despite this, researches distinguish five common subtypes of Internet (cyber) addiction: passion for cyber relationships, addiction to cybersex, online obsessions (shopping, sale, gambling), information surfing and gambling - computer game addiction) according to the capabilities offered by the Network (accessibility, information flow limitless, platforms for communication and dating, etc.) and social issues (social isolation, loneliness, family problems and etc.) that person has in real life. Actual needs of older boys and girls (communication, self-presentation, love, friendship, recognition, 
popularity, etc.) can be implemented in cyber relationships on social networks, which, in addition, technologically designed to capture attention of young people, which eventually leads to an obsessive drive and dependencies. Based on the social and educational paradigm of socio-pedagogical activity construction we have proposed high school students' dependence on social networks social and pedagogical prevention technology development, using discussion and game cinema film analysis as an effective means of developing personality social traits of high school students, based on the psycho-age features of young people. These suggestions are also informative for future research direction and hold important implications for social workers' socio-pedagogical activities at school.

Key words high school students, cyberspace, cyber dependency, high school students' dependence on social networks, socio-pedagogical prevention, film as a means of social and pedagogical prevention.

Удк 378.1:004.77

Наталія Приходькіна

Державний заклад вищої освіти «Університет менеджменту освіти» ORCID ID 0000-0002-6211-5546 DOI 10.24139/2312-5993/2020.01/094-103

\section{НАВЧАЛЬНА ПРОГРАМА 3 МЕДІА- ТА ІНФОРМАЦІЙНОЇ ГРАМОТНОСТІ ЮНЕСКО: КОНЦЕПТУАЛЬНІ ОСНОВИ}

У статті авторкою окреслено концептуальні основи навчальної програми 3 медіа- та інформаційної грамотності, розробленої ЮНЕСКО. Пропоновані в Програмі ідеї та підходи дозволяють вивчати теорію та практику впровадження медіа- та інформаційної грамотності в педагогічну освіту. Метою Програми $\epsilon$ підтримка педагогів у засвоєнні компетентностей медіа- та інформаційної грамотності для розробки й реалізачії відповідної навчальної програми для середньої школи. Концептуальною основою Програми є три широкі складові медіа- та інформаційної грамотності: створення тексту, власне текст, аудиторія. У Програмі виділено одинадиять модулів, що висвітлюють ключові теми та проблеми сучасних медіа. Модулі, включені в Навчальну програму, можуть бути інтегровані в уже існуючі курси або об'єднані для створення окремого курсу з медіа й інформаційної грамотності.

Ключові слова: інформачійна грамотність, медіаграмотність, інформаційна компетентність, медіакомпетентність, компетентність, навчальна програма, навчальна програма з медіа- та інформачійної грамотності, ЮНЕСКО, вчителі.

Постановка проблеми. Сучасне суспільство, перебуваючи на новому історичному етапі розвитку цивілізації, так зване «інформаційне суспільство», в якому головні продукти виробництва - інформація та знання.

Сучасна молодь, народжена в цифрову епоху, звикла використовувати медіа більш різноманітно й активно, ніж представники попередніх поколінь, незважаючи на можливість необмеженого доступу до цифрових медіа всіх поколінь без винятку. Народжене на початку XXI століття, так зване «покоління Z» - «цифрові аборигени», діти 